\title{
U.S. Taxation Of The Value Of Executive Services Performed For Multinational Joint Ventures
}

Martin A. Goldberg, J.D., LL.M., University of New Haven, USA

Robert E. Wnek, J.D., LL.M., CPA, University of New Haven, USA

Jacqueline S. Pineau, M.S., University of New Haven, USA

\begin{abstract}
Domestic U.S. businesses forming a joint venture with a commonly-controlled foreign affiliates need always to take into account transfer pricing rules, whereby any income, deductions, or credits or one may be reallocated from one of the businesses to the other. This problem provides special concerns with regards to compensation for executive services, where calculation of an arm's length amount is more difficult, and where other contractual rights may have an impact on the determination of the arm's length amount. The concept of transfer pricing rules with regard to services was first addressed in 1968 regulations, after which there were temporary regulations in 2003 that were finalized in 2009. However, there are still many issues that have not been addressed, that will need to be resolved in a future set of regulations.
\end{abstract}

Keywords: Tax; Multinational; Executive Services; Joint Ventures

\section{INTRODUCTION}

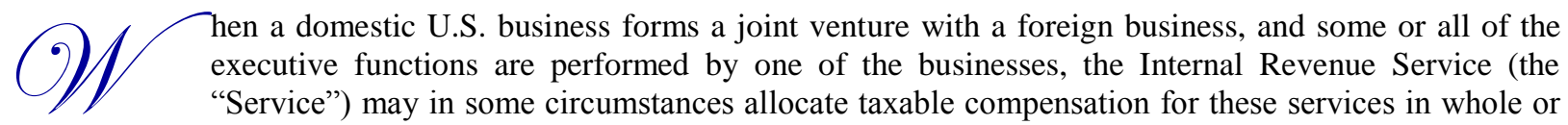
in part to the other business. The result of this may be an increase in the taxable income of the U. S. business.

The source of the problem is section 482 of the Internal Revenue Code (the "Code"), which authorizes the Service to allocate income and deductions between or among commonly-controlled businesses.

Generally, Code $\$ 482$ allows the Secretary to redistribute income and expenses among related parties if it is determined the prices charged, or income allocated, for any related party transaction was calculated in such a way that the primary purpose was tax avoidance. ${ }^{1}$ All intercompany transactions must be priced using an arms length standard. $^{2}$ If the results are comparable to what an unrelated party would have paid for the service or if the related party would have paid an unrelated party the same or similar price for the service, this would indicate an arm's length charge.

One of the purposes for which Code $\S 482$ was enacted was "due to the variance in tax rates (and tax systems) among countries, and possibly for other reasons, a multinational enterprise may have a strong incentive to shift income, deductions, or tax credits among commonly controlled entities to the entity in the most favorable tax jurisdiction in order to arrive at a reduced overall tax burden. Such a shifting of items between commonly

\footnotetext{
${ }^{1}$ Code $\$ 482$

2 Treas. Reg. $\$ 1.482-1(b)(1)$

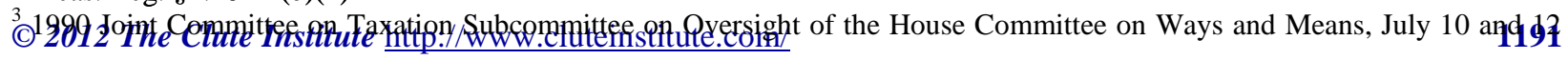


controlled entities might be accomplished by setting artificial transfer prices for transactions between group members." 3

For years Code $\$ 482$ has been the primary tool used to attack transfer pricing, where a U.S. domestic business artificially inflates costs charged by a foreign subsidiary, in order to decrease U.S. taxable income while increasing taxable income in a foreign country with lower tax rates. Although traditionally applied to overcharges in the cost of assets sold from the foreign company to the domestic company, the principle can also apply to undercharges in the cost of services rendered by the domestic company to the foreign company. Under Treas. Reg. 1.482-2(b), when there is no charge for "marketing, managerial, administrative, technical, or other services," or when the charge is not an arm's length amount, the Service is empowered to make an allocation to reflect an arm's length amount. Thus, the company through which such services are performed will be taxed as though it had received the value of such services, regardless of the amount that the company is actually paid for such services.

Code $\$ 482$ does not expressly target international transfer pricing arrangements, and only notes parenthetically that it applies whether or not a business is domestic or foreign. Although facially neutral in this regard, its use in international transactions arises from the potential for abuse inherent when commonly-controlled companies do business under different taxation regimes, one with a higher rate of income taxes, and the other with a lower rate of income taxes or otherwise a more favorable tax system.

This article will explore two components of this issue. First, this article discusses methodologies for quantifying the value of the compensation that may be imputed to the business offering such services. Second, this article will discuss the shortcomings of existing methods and analyze policy issues for possible future methodologies.

\section{BACKGROUND}

\section{Regulations}

Transfer pricing Treasury regulations for intercompany services were initially issued in 1968. At that time, the major industry in the United States was manufacturing, compensation for executive services was relatively low, and the issue of transfer pricing for services was still one that had not drawn a great deal of attention.

Under the 1968 regulations, intercompany services were covered in Treasury regulation $\S 1.482-2$ (b). In the 1968 regulations there is a concept of integral services and non-integral services. If a service is deemed to be a service which is integral to the renderers business, the arms length charge for the service is generally cost plus a markup. If a service is deemed to be non-integral to the business, the amount allocated to related parties would be costs only or nothing at all depending on the facts and circumstances of the activity.

The general rule in the 1968 regulations required that when one member of a controlled group performs marketing, managerial, administrative, technical or other services on behalf or, or for the benefit of another member of the controlled group the renderer of the service must be compensated. ${ }^{4}$ An allocation must be made if the service provided is for the benefit, or the potential benefit, of the related party. Costs muse be allocated even if the potential benefits anticipated are not realized. As is the case in the temporary regulations which were promulgated later in 2003, discussed below, if the benefit to the recipient of the services is so indirect or remote that unrelated parties would not have charged for the services, no allocation would be necessary. ${ }^{5}$ Also, if the service were duplicative, the service would not be considered to provide a benefit to the recipient and no allocation of costs would be required. ${ }^{6}$

\footnotetext{
${ }^{3} 1990$ Joint Committee on Taxation Subcommittee on Oversight of the House Committee on Ways and Means, July 10 and 12 1990.

${ }^{4}$ Treas. Regs. $\$ 1.482-2(b)(1)$

5 Treas. Regs. $§ 1.482-2(\mathrm{~b})(2)(\mathrm{i})$

${ }^{6}$ Treas. Regs. $\$ 1.482-2(\mathrm{~b})(2)(\mathrm{ii})$
} 
When an allocation is necessary for intercompany services, the cost allocated must be an arm's length charge. The charge for services provided must be the same as the charge would have been if similar services had been provided by unrelated parties under similar circumstances. ${ }^{7}$ The 1968 regulations did not provide for a best method rule. The only method discussed with regards to allocation of service costs related to the cost only approach. ${ }^{8}$ The cost only method, or cost safe harbor method, applied to services which are not an integral part of the business activity. In such a case, an arm's length charge would be equal to the costs or deductions incurred with respect to the services provided. Adequate books and records were required to verify costs/deductions.

The costs or deductions to be taken into account when charging out intercompany services, whether an integral part of the business or not, included all the costs or deductions directly or indirectly related to the service performed. ${ }^{9}$ Direct costs would include compensation, bonuses, travel attributable to employees directly involved in performing the service, material and supplies consumed in rendering such service and other costs. Indirect costs relate to direct costs addressed above and generally include cost of utilities, occupancy, supervisory and clerical compensation, and other overhead burden of the department incurring the direct cost. Certain costs and deductions that should not be included in calculating total service costs include interest expense on indebtedness not incurred specifically for the benefit of another member of the group, stock issuance and maintenance of shareholder relations, and expenses of compliance with regulatory or legal filings which are not directly related to the service in question $^{10}$. These non-allocable costs were similar to those included in the Temporary regulations described below.

When services rendered are in integral part of the business activity, a cost only allocation might not be appropriate. An analysis must be done to determine if the service provided in an "integral" part of the business to either the party providing the service or the member receiving the benefit. There are four alternative tests to determine if a service is integral to the business.

The first test is the trade or business test ${ }^{11}$. Services are generally viewed as being an integral part of the business if the renderer or recipient is engaged in the trade or business of rendering similar services to one or more unrelated parties.

The second test is the principal activities test ${ }^{12}$. A service is integral if the renderer provides services to one or more related parties as one or its principal business activities. There is a $25 \%$ test to determine if the activity is a principal business activity. If the costs of providing the services to related parties are less than $25 \%$ of the total costs of rendering those services, the activity is generally not viewed as a principle business activity. If the $25 \%$ threshold is met or if the service involves manufacturing, production, extraction or construction activities, facts and circumstances will be used to determine if the activity is a principle business activity ${ }^{13}$. Some facts and circumstances that would be considered include time devoted to rendition of services, regularity with which services are rendered, amount of capital investment, risk or loss involved and whether the services are in the nature of supporting services or independent of other activities of the renderer. ${ }^{14}$

The third test to determine if a service is integral is the peculiarly capable standard ${ }^{15}$ which states that when the renderer of services is peculiarly capable of rendering the services and such services are a principal element in the operations of the recipient the service would be integral to the business. The renderer is peculiarly capable of rendering services where the renderer, in connection with rendering the service, makes use of a particularly advantageous situation or utilization of an influential relationship. To be considered peculiarly capable, the value of the services must be substantially in excess of the costs of the renderer attributable to such services. ${ }^{16}$

\footnotetext{
${ }^{7}$ Treas. Regs. $\$ 1.482-2(\mathrm{~b})(3)$

8 Wrappe, Steven C. and Trauman, Brian P TM Memorandum “The New Service Regulations: Are we There Yet?"

${ }^{9}$ Treas. Regs. $§ 1.482-2(\mathrm{~b})(4)(\mathrm{i})$

${ }^{10}$ Treas. Regs. $\$ 1.482-2(\mathrm{~b})(5)$

${ }^{11}$ Treas. Regs. $\$ 1.482-2(b)(7)(i)$

${ }^{12}$ Treas. Regs. $\$ 1.482-2(\mathrm{~b})(7)(\mathrm{ii})$

${ }^{13}$ Wrappe, Steven C. and Trauman, Brian P TM Memorandum “The New Service Regulations: Are we There Yet?"

${ }^{14}$ Treas. Regs. $\$ 1.482-2(\mathrm{~b})(7)(\mathrm{ii})(\mathrm{A})$

${ }^{15}$ Treas. Regs. $\$ 1.482-2(\mathrm{~b})(7)(\mathrm{iii})$

${ }^{16}$ Treas. Regs. \$1.482-2(b)(7)(iii)
}

(C) 2012 The Clute Institute http://www.cluteinstitute.com/ 
The fourth and final test to determine if a service is an integral part of the business is if the recipient has received the benefit of a substantial amount of services from one or more related parties during the taxable year. A substantial amount is defined as exceeding $25 \%$ of the total costs of the recipient.

Costs to be included in determining the substantial amount include all costs directly or indirectly related to the rendition of manufacturing, production, extraction or construction activities. Costs should exclude cost of goods sold. ${ }^{18}$ For purposes of the $25 \%$ test, a consolidated group may at the option of the taxpayer, be viewed as one renderer of the services. ${ }^{19}$

The 1968 regulations provided guidance on the methods allowed to allocate and apportion both direct and indirect costs. The use of one or more bases to allocate costs may be appropriate, consideration should be given to all bases and factors including, total expenses, payroll, space utilization and time spent. The costs incurred by supporting departments may be apportioned by a reasonable overall estimate or by a departmental overhead rate. ${ }^{20}$

\section{Temporary Regulations}

Over the years, services have become a more important part of the U. S. economy. This transformation places a greater emphasis on the pricing of services between related parties. While the majority of the transfer pricing regulations under Code $\S 482$ were updated in the mid-1990's, service regulations were not addressed at that time.

In 2003, however, proposed intercompany service regulations were issued. These were intended to make the pricing of intercompany services less burdensome to the taxpayer. This goal, however, was contradictory with some of the concepts in the proposed regulations. One example of this is the simplified cost base method (SCBM). Many taxpayers and commentators felt that the application of the proposed regulations would have imposed additional documentation burdens and controversy risk on most multinational companies ${ }^{21}$. Taking these concerns into account, Treasury modified proposed regulation section 1.482-9P and issued temporary regulation section 1.482-9T on August 1, 2006. These temporary regulations give taxpayers the guidance needed to ensure that intercompany services are being charged using the arm's length standard.

\section{Final Treasury Regulations}

Final regulations on controlled service transactions were issued on July $31,2009 .{ }^{22}$ While these were substantially the same as the temporary regulations, they additionally addressed some of the problems that had arisen under the temporary regulations.

It is important to note that Code $\S 482$ may only be utilized or imposed by the Treasury Department. The section empowers the Secretary to allocate income and deductions between taxpayers and prescribe the regulations accordingly. This is a difficult area primarily due to the variety of circumstances between taxpayers and the availability of data to implement allocations. The new regulations may be perceived as reinforcement of the methods used to an attempt to standardize service allocations under Code $\$ 482$.

\section{Administrative Services}

The final controlled service transaction regulations provide taxpayers with updated rules to calculate the cost a company can allocate for services. Specific methods are identified for back office and administrative services

\footnotetext{
${ }^{17}$ Treas. Regs. $\$ 1.482-2(\mathrm{~b})(7)(\mathrm{iv})$

${ }^{18}$ Treas. Regs. $\$ 1.482-2(\mathrm{~b})(7)(\mathrm{ii})(\mathrm{B})$

${ }^{19}$ Treas. Regs. $\$ 1.482-2(\mathrm{~b})(7)(\mathrm{ii})(\mathrm{C})$

${ }^{20}$ Treas. Regs. $\$ 1.482-2(\mathrm{~b})(6)(\mathrm{ii})$

${ }^{21}$ Ryan, James and Wolosoff, Todd. "Temporary Services Regs: One Step Forward, Two Steps back?"

${ }^{22}$ Treas. Reg. §1.482-9
} 
as well as methods for pricing "high value" services which require a mark up. The specific methods introduced in the temporary regulations, to establish arms length transfer prices are as follows:

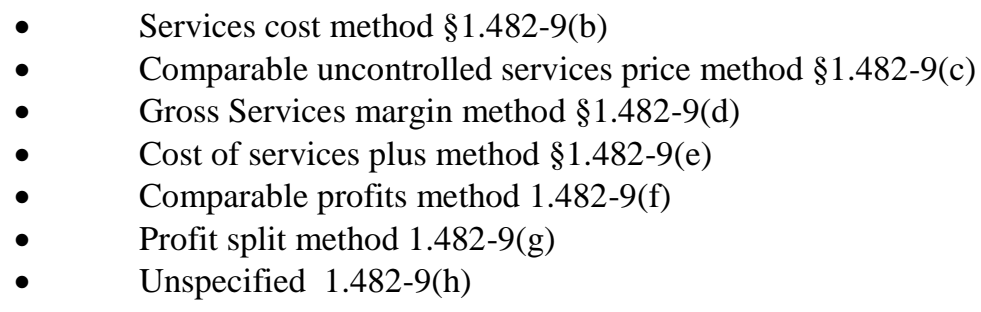

The above methods were substantially maintained in the final regulations. The controlled service transaction regulations follow the "best method" rule under Regulation \$1.482-1(c) which requires the taxpayer to use the method that provides the most reliable measure under the facts and circumstances of the transaction. The results of the service transaction must also follow the comparability standards under Regulation \$1.482-1(d). To determine if the related party charge is arm's length, the results need to be compared to a comparable transaction with an uncontrolled party under similar circumstances. Finally the price charged for services must fall with the arm's length range as set forth in Regulation \$1.482-1(e).

The majority of the methods used to establish an arms length transfer price relate to high margin transactions which require a mark up. However, the Service Cost Method ("SCM") relates to low margin services which are charged out at cost. This is important to note because the original 1968 regulations provided for a cost only safe harbor method which allowed the taxpayer to allocate the cost incurred to perform certain low margin services without any markup. ${ }^{23}$ The SCM applies the same cost only concept but includes more specific definitions and rules to be followed. The IRS and Treasury wanted to keep a cost only provision for certain back office services which are similar across industries, that generally have a low mark up and that do not significantly contribute to the success or failure of the business. The cost only approach is intended to minimize the compliance burdens applicable to these services. ${ }^{24}$

The services cost method, $\S 1.482-9$ (b) replaced the cost only safe harbor method in the 1968 regulations and still allows the taxpayer to charge out certain services at cost while reducing the compliance burdens on these services. ${ }^{25}$ The SCM replaces the simplified cost base method ("SCBM") established in the proposed regulations issued in 2003 which was a controversial aspect of the proposed regulations. Treasury's intent with the SCBM was, to reduce the compliance burden for back office services, however, the way in which the rules worked, taxpayers would potentially have to use outside consultants, and spend substantial sums of money, to prepare comparability analysis to support the use of the $\mathrm{SCBM}^{26}$. The SCM is a method the taxpayers can follow which is less burdensome to comply with.

In order to use the SCM certain conditions must be met. When all of the conditions are met and the intent to use the SCM is clearly identified in the books and records, the SCM will be considered the best method for purposes of $\$ 1.482-1(\mathrm{c})$ and the services should be charged out without a markup. Failure to meet any of the requirements disqualifies the taxpayer from using the SCM.

The first condition is that the services be considered "covered services", whether they are specified covered services or low margin covered services. Specified covered services ${ }^{27}$ are services identified by the IRS in IRS Announcement 2006-50, modified by Rev. proc 2007-13. The covered services are generally support services which do not involve significant arms length markup and are common among industry sectors ${ }^{28}$. The low margin

\footnotetext{
${ }^{23}$ Treas. Reg. $\$ 1.482-2(b)$

${ }^{24}$ TD 9278, Preamble to 2006 Temporary regulations, A(1)(a)

${ }^{25}$ TD 9278, Preamble to 2006 Temporary regulations,

${ }^{26}$ TD 9278, Preamble to 2006 Temporary regulations, A(1)(a)

${ }^{27}$ Treas. Reg. $\$ 1.482-9 T(b)(3)(4)(i)$

${ }^{28}$ TD 9278, Preamble to 2006 Temporary regulations, A(1)(b)
}

(C) 2012 The Clute Institute http://www.cluteinstitute.com/ 
covered services $^{29}$ are identified by the tax payer. Low margin services are defined as services that have a median comparable markup on total services costs of less than or equal to 7\%. The mark up is determined using general $\S 482$ principles and the arm's length markup is based on the median comparable markup on total services costs. The low margin covered services category allows the taxpayer to use the SMC even if the service is not on the list of covered services as long as the taxpayer can satisfy the business judgment rule and the service is not on the list of specifically excluded activities.

The second requirement is that adequate books and records must be maintained which contain sufficient detail to identify the total service costs, the nature of the service, identification of the renderer of the service and the recipient of the service and the allocation and apportionment method of the costs ${ }^{30}$. Also, a statement of the intention to use the SMC must be included. Although this seems like simple enough requirements, the challenge will be implementing changes to accounting systems and procedures to account for the required documentation. ${ }^{31}$ The SCM will only be considered the best method for purposes of $\$ 1.482-1(\mathrm{c})$ is if a statement of intent to use the SCM is included in the books and records. ${ }^{32}$ By requiring the statement of intent, the taxpayer can control whether to apply the SCM or not, rather than requiring the taxpayer to use the SCM when all conditions are met.

The third requirement to use the SCM is that services provided can not be on the list of specifically excluded activities, so called the "blacklist". There are nine categories included on the blacklist and include activities such as manufacturing, distributions, construction, and financial transactions ${ }^{33}$. These services are viewed by the IRS and Treasury as "high margin" services which would require a more thorough arm's length evaluation.

The final condition that must be met is that the taxpayer must "reasonably conclude" that these services do not contribute significantly to key competitive advantages, core capabilities or fundamental risks of success or failure in one or more trades or businesses of the renderer, the recipient or both - referred to as "the business judgment rule" ${ }^{34}$. The final regulations clarify that the business judgment rule should be based on the trade or business activity of the controlled group. ${ }^{35}$ In all but unusual cases, the taxpayer's business judgment will be respected. The focus of an examination would be on verification of total service costs and the allocation of those $\operatorname{costs}^{36}$. In the final regulations, the IRS has clarified that the taxpayer must come to a reasonable conclusion which will be considered the starting point on the analysis and may be subject to examination by the IRS upon audit. ${ }^{37}$ The business judgment rule will apply on a case-by-case basis and the taxpayer's specific facts and circumstances will be taken into account.

\section{High-Value Services and High-Margin Transactions}

While the SCM method is attractive for its ease of application, it would be inapplicable to compensation for executive services, primarily for two reasons. First, these are high margin transactions. Second, such services directly affect competitive advantage.

For high margin transactions that require a mark up, the new regulations identify several methods to calculate an arm's length price. The first method for calculating arm's length price on high margin transactions is the comparable uncontrolled services price method ${ }^{38}$. This method is used to evaluate whether a controlled services transaction is arm's length by comparing the price charged in a controlled services transaction to that of an

\footnotetext{
${ }^{29}$ Treas. Reg. §1.482-9T(b)(4)(ii)

${ }^{30}$ Various North American Tax, Transfer Pricing Subpractice Group Members. "ALERT: Treasury and IRS Issued Temporary and Proposed Regulations on Intercompany Service and Intangible Transactions".

${ }^{31}$ Burns, Paul B. "International implications of the services costs method of the new US transfer pricing regulations"

${ }^{32}$ RIA Federal Tax Weekly Alert, "IRS Issues long awaited final transfer pricing regs on controlled service transactions - Part I", 8/6/9009-Volume 55, No. 32

${ }^{33}$ Treas. Reg. $\$ 1.482-9 \mathrm{~T}(\mathrm{~b})(3)(\mathrm{ii})$

${ }^{34}$ Treas. Reg. 1.482-9T(b)(2)

${ }^{35}$ TD 9456, Preamble to Final Regulations $\$ 1.482-9$, A(1)(e)

${ }^{36}$ TD 9278, Preamble to 2006 Temporary regulations, A(1)(b)

${ }^{37}$ TD 9456, Preamble to Final Regulations $§ 1.482-9$, A(1)(e)

${ }^{38}$ Treas. Reg. $\$ 1.482-9 T(c)(1)$ 
uncontrolled services transaction. This method is analogous to the comparable uncontrolled price, or CUP, method under $\S 1.482-3(\mathrm{~b})$. The uncontrolled services price method is substantially the same in the final regulations. ${ }^{39}$

The second method for high margin transactions is the gross services margin method ${ }^{40}$ which will typically be used when a controlled taxpayer performs activities such as agency or intermediary services in connection with an uncontrolled transaction between a member of the controlled group and an uncontrolled taxpayer. The arm's length price should be calculated by reference to the gross margin realized in a comparable uncontrolled transaction. This method is analogous to the resale price method in 1.482-3(c).

The third method for high margin transactions is the cost of services plus method ${ }^{41}$ which is used to evaluate the amount charged in a controlled services transaction by reference to the gross services profit mark up in comparable uncontrolled services transactions. This method is analogous with cost plus method in 1.482-3(d). The cost of services plus method is generally used for service transaction where the renderer of the controlled services provides the same or similar services to both controlled and uncontrolled parties as this would be the only way that the taxpayer would have the detailed comparable costs necessary to apply this method. ${ }^{42}$ There is no change to this method in the final regulations. ${ }^{43}$

The fourth method for high margin transactions is the comparable profits method which is used to evaluate whether the amount charged in a controlled services transaction is arm's length by reference to objective measures of profitability ("profit level indicators", PLI) derived from unrelated parties that engage in similar activities under similar circumstances. ${ }^{44}$ This method will only apply where the renderer of controlled services is the tested party. ${ }^{45}$ In addition to the profit level indicators as provided for in Treasury Regulation $\$ 1.483-5(b)(4)$, a ratio of operating profits to total services costs may be used as a PLI. ${ }^{46}$

The fifth method for high margin transactions provided is the profit split method ${ }^{47}$ which is used to evaluate whether the allocation of the combined operating profit or loss attributable to one or more controlled transactions is arm's length by reference to the relative value of each controlled taxpayer's contributions to the combined profit or loss. Generally, this method applies if a controlled services transaction has one or more material elements for which it is not possible to determine market-based return. This method is analogous to the profit split method in Treasury regulation \$1.482-6. The profit split method will likely be applied only in special fact patterns that are not common to most multinationals. ${ }^{48}$ The final regulations clarify that the profit split method may not be used where only one taxpayer makes non-routine contributions. ${ }^{49}$

The final method for high margin transactions is unspecified methods. Unspecified methods may be used to evaluate if an arm's length price for services has been charged. ${ }^{50}$ The unspecified method allows taxpayer the flexibility to consider non-service alternatives to a services transaction. ${ }^{51}$ The unspecified method must take into account the general principle that uncontrolled taxpayers compare the terms of a particular transaction to the realistic alternatives to that transaction, including economically similar transactions structured as other than services transactions.

\footnotetext{
39 TD 9456, Preamble to Final Regulations $§ 1.482-9$, (A)(2)

${ }^{40}$ Treas. Reg. $\$ 1.482-9 \mathrm{~T}(\mathrm{~d})(1)$

${ }^{41}$ Treas. Reg. $\$ 1.482-9 T(\mathrm{e})(1)$

${ }^{42}$ Various North American Tax, Transfer Pricing Subpractice Group Members. "ALERT: Treasury and IRS Issued Temporary and Proposed Regulations on Intercompany Service and Intangible Transactions", 9

${ }^{43}$ TD 9456, Preamble to Final Regulations $\$ 1.482-9$, (A)(3)

${ }^{44}$ Treas. Reg. $\$ 1.482-9 T(f)$

45 Treas. Reg. $\$ 1.482-9$ T(f)(2)(i)

${ }^{46}$ Treas. Reg. $\$ 1.482-9 \mathrm{~T}(\mathrm{f})(2)(\mathrm{ii})$

${ }^{47}$ Treas. Reg. $\$ 1.482-9 T(\mathrm{~g})$

${ }^{48}$ Ryan, James and Wolosoff, Todd. "Temporary Services Regs: One Step Forward, Two Steps back?"

${ }^{49}$ Treas. Reg. $\$ 1.482-9(\mathrm{~g})(1)$

${ }^{50}$ Treas. Reg. §1.482-9T(h)

51 TD 9278, Preamble to 2006 Temporary regulations, (A)(7)
}

(C) 2012 The Clute Institute http://www.cluteinstitute.com/ 
In addition the updated rules for calculating the cost allocated for services, the temporary regulations also allow for contingent payments in service transactions. ${ }^{52}$ If a contingent payment arrangement exists, the recipient of services will not be required to make a payment to the renderer of services until the specific contingency occurs. In order for an arrangement to be treated as a contingent payment arrangement there must be a written contract, enacted before or contemporaneous with the controlled services being provided, the contract must state the payment is contingent on future benefits for the recipient of the controlled services transaction and the contract must provide for payment that reflects the recipients benefit as well as the risks born by the renderer in lieu of being compensated during the period in which service occurred. ${ }^{53}$ The commissioner has the authority to impute contingent payment terms if the economic substance of the terms is not a consistent intercompany arrangement. ${ }^{54}$ The final regulations add that when the Commissioner exercises its authority to impute the contract terms, the taxpayer may present additional facts to indicate if an alternative agreement best reflects the economic substance of the underlying transaction. ${ }^{55}$

The temporary regulations had set out to define total services costs or the cost base that can be charged out. The total services cost is needed to determine arm's length in the comparable profits method and costs included in the services cost method. Total services costs include all costs directly identified with the service, plus other costs that are reasonably allocated to such services. All contributions in cash or cash in kind (including stock based compensation) are includable in total service costs. The inclusion of stock based compensation has potential to have significant impact on companies that rely heavily on stock based compensation. ${ }^{56}$ Generally Accepted Accounting Principles ("GAAP") and tax accounting principles can not be relied on as the sole determination as to what is included as service costs. Costs should comprise provision for all resources expended, used, or made available to achieve the specific objective for which the service is rendered. ${ }^{57}$ The definition of the cost base is closer to a cost accounting view or resources allocated to the service. ${ }^{58}$ The definition of total service costs is substantially unchanged in the final regulations. ${ }^{59}$

The temporary regulations define a controlled service transaction. A controlled service transaction is any activity by one member of a group of controlled taxpayers which results in a benefit to one or more other members of the controlled group. ${ }^{60}$ An activity includes the performance of functions, assumptions of risk, or use by a renderer of tangible or intangible property or other resources, capabilities, or knowledge. ${ }^{61}$ This broad definition of service is consistent with Treasury's current overall approach of seeking consistent transfer pricing analysis for economically similar transactions. ${ }^{62}$ An activity is considered to provide a benefit to the recipient if the activity directly results in a reasonably identifiable increment of economic or commercial value that enhances the recipient's commercial position, or that may be reasonably anticipated to do so. ${ }^{63}$ The temporary regulations shift the focus of who receives the benefit from the render to the recipient of the activity ${ }^{64}$.

There are certain activities that are considered to not confer a benefit on the recipient and therefore no allocation of costs would be appropriate. An activity that provides an indirect or remote benefit such that the recipient would not be willing to pay for it or would not be willing to perform the activity themselves is not

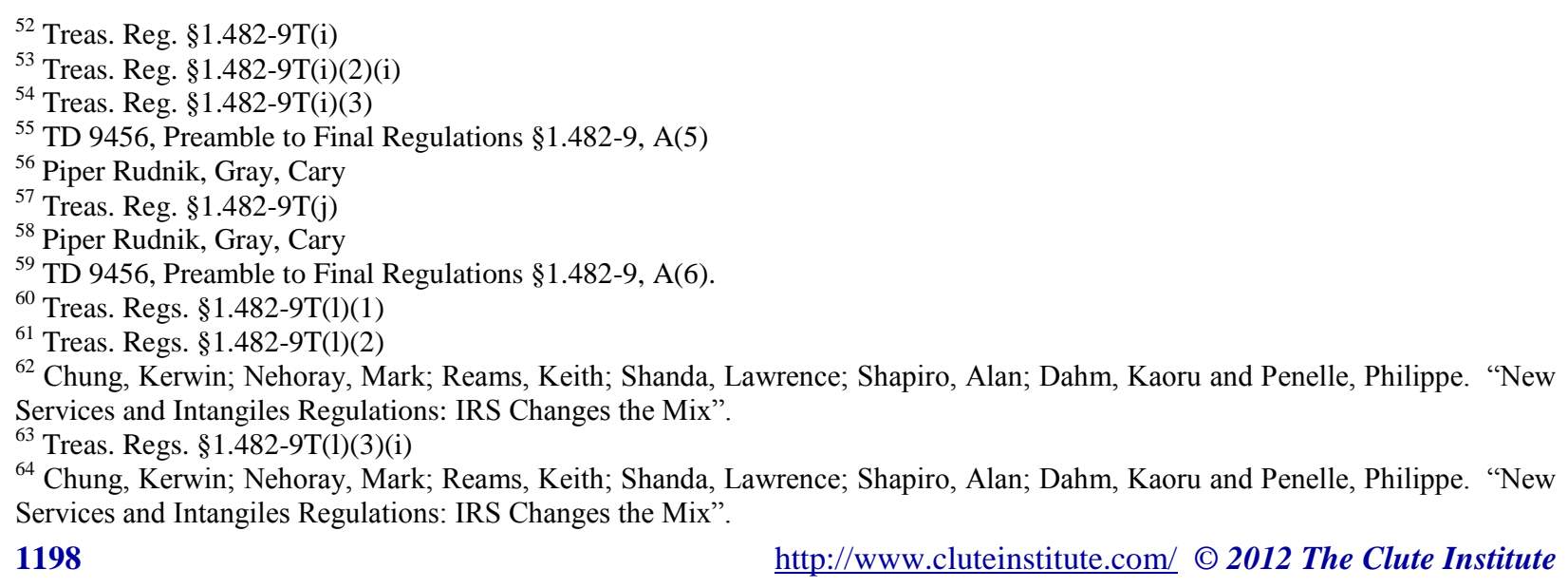


considered to provide a benefit. ${ }^{65}$ The temporary regulations differentiate between shareholder activities and duplicative activities, both of which are viewed as not providing a benefit to the recipient. An activity that duplicates activities performed by affiliates will not be considered to provide a benefit, unless the duplicative activity provides an additional benefit to the recipient. ${ }^{66}$ An activity whose sole effect is to protect the renderer's capital investment in the related party or if the activity facilitates compliance with reporting, legal or regulatory requirements would not provide a benefit to the recipient and are not costs eligible to be charged out. ${ }^{67}$ A benefit merely due to association with the controlled group is not a service transaction and therefore not eligible for costs to be charged out. ${ }^{68}$

The effective date of the temporary regulations was originally for tax years beginning after December 31 , 2006 (with retroactive application for tax years beginning after 9/10/03. Notice 2007-5 modified the effective date for identifying controlled services eligible to be priced at cost. Provisions related to the SCM went into effect for tax years beginning after 12/31/2007. The business judgment rule still applies effective 12/31/2006. The final regulations apply to tax years beginning after July 31, 2009.

\begin{abstract}
ANALYSIS
With the introduction of the services cost method to replace the cost safe harbor rule in the 1968 regulations, the IRS was intending to lessen the burden on taxpayers for allocating low margin back office services which are common among taxpayers. The IRS felt that the cost safe harbor rule allowed too much flexibility and that some taxpayers were abusing this flexibility and charging out high value added services at cost. ${ }^{69}$ For specifically identified covered services, no additional economic analysis is required to support the cost only charge. However, there are a wide variety of services that will not be covered for the cost method and there is additional burden on the tax department to prepare the analysis required for many of these services. ${ }^{70}$
\end{abstract}

The temporary regulations provide a more organized method to calculate the intercompany charge for service fees; however, this leads to added work for the tax department. All services have to be tracked to determine what type of service is being provided and to whom. If it is a service directly attributable to the related party, the cost should be allocated without markup. If the service is a shareholder service or duplicative service, no cost allocation should be made. If the service is determined to be an allocable service, the determination needs to be made as to what the correct allocation is, cost or cost plus. The proper analysis and proper documentation of to this adds considerable work to the tax department. The transfer pricing documentation must be ready by the time the return is filed to support the allocation of costs. .

Under the temporary regulations, more headquarter charges will be allocated out than were done in the past. The temporary regulations provide more guidance as to what is considered shareholder expense, or stewardship costs, and what is considered duplicative costs. The definition of shareholder expenses places an emphasis on the "sole effect" of the activity is to protect the renderer's capital investment, etc. The IRS's intention is to place a much narrower limit on the types of costs that are not allocated out. ${ }^{71}$ As these expenses were not allocated out in the past, foreign taxing authorities could challenge these charges.

Changes made to the benefit rule will also affect the amount of charges that will be required to be allocated out. Under both sets of regulations, in order for a service to be charged out, the benefit rule has to apply. Under the 1968 regulations, the benefit rule was applied from the service providers prospective. Generally, if a service was provided for the benefit of another member of the controlled group, the renderer of the service should be

\footnotetext{
${ }^{65}$ Treas. Regs. $\$ 1.482-9 T(1)(3)(i i)$

${ }^{66}$ Treas. Regs. \$1.482-9T(1)(3)(iii)

${ }^{67}$ Treas. Regs. $\$ 1.482-9 \mathrm{~T}(1)(3)(\mathrm{iv})$

${ }^{68}$ Treas. Regs. §1.482-9T(1)(3)(v)

${ }^{69}$ Burns, Paul B. "International implications of the services costs method of the new US transfer pricing regulations"

${ }^{70}$ Ryan, James and Wolosoff, Todd. "Temporary Services Regs: One Step Forward, Two Steps back?"

${ }^{71}$ Chung, Kerwin; Nehoray, Mark; Reams, Keith; Shanda, Lawrence; Shapiro, Alan; Dahm, Kaoru and Penelle, Philippe. "New Services and Intangiles Regulations: IRS Changes the Mix"
}

(C) 2012 The Clute Institute http://www.cluteinstitute.com/ 
compensated $^{72}$. As discussed above, there are exceptions to allocating costs to the related party, such as duplicative services and a remote or indirect benefit. Under the new regulations, the benefit rule applies from the recipient's perspective. ${ }^{73}$ If, in comparable circumstances, the recipient would have paid an unrelated party to perform the service or would perform the services themselves, the activity will generally be viewed as conferring a benefit to the related party and the service provider should be compensated ${ }^{74}$.

Transfer pricing in general, not only for services, had become an area of great interest to the IRS. In light of the economic crisis in the United States and the deficit position the country is in, the IRS is looking in all areas for revenue. Per the IRS website, a directive was issued in 2003 which states that at the beginning of an audit cycle, an information document request ("IDR") for transfer pricing documentation must be issued pursuant to §6662(e). If it is determined that the transfer price set by the taxpayer is incorrect, the penalties could be very steep, 20 to $40 \%$ of the adjustment, depending on the size of the net adjustment ${ }^{75}$. However, if the taxpayer can prove that the transfer pricing was reasonable applied and documented, no penalties will be issued. This goes to show that taxpayers need to make sure that the correct transfer prices for services are set and that all controlled service transactions as defined in the temporary regulations ${ }^{76}$ and discussed above are being properly allocated to intercompany affiliates.

It is notable that transfer pricing is not the only area of the law where the value of compensation for executive services will be scrutinized.

U. S. federal tax case law contains numerous cases involving the correctness of amounts paid as compensation for services. Historically, the taxpayers in these cases are domestic C corporations seeking to peg compensation for services rendered by owner-managers as high as possible, in order to deduct amounts that would otherwise be taxed twice, first as corporate income and as then dividends to the shareholders.

At the other end of the spectrum, the cases where compensation for services is stated as low as possible are far more rare. In the past, there have been cases where the owner-manager of an $\mathrm{S}$ corporation attempted to draw a low salary in order to minimize payroll taxes, but these cases are relatively infrequent. ${ }^{77}$

It is likely that there will be more of these low-compensation cases in the future, as a result of two phenomena: One, the fact that the wage base on which payroll taxes is calculated continues to increase, making the prospect of a reasonable compensation below that level something that is attainable to a greater number of individuals. Two, the temporary (as extended, through 2012) tax law provision taxing dividend income at capital gains rate, which will create an incentive for the owner-manager of a $\mathrm{C}$ corporation also to understate compensation. Even if this tax provision is not extended past the year 2008, it will still leave in its wake a body of case law where the Service will have argued that the provider of services should have received greater compensation for those services than the amount actually paid. This body of case law will be relevant in transfer pricing cases where there is an issue regarding the adequacy of compensation for services.

One thing demonstrated by these cases is the difficulty of establishing fair compensation for executive services. First, there is a wide range of levels of compensation, even among unrelated parties. Second, compensation may be affected by other factors, such as whether there is a generous severance package or, on the other hand, restrictive provisions on termination of employment. Third, the level of compensation may be affected by the financial stability of the company. Thus, something as critical as the fair collection of revenues by the United States hinges on something as ephemeral as fair value for executive compensation.

\footnotetext{
${ }^{72}$ Treas. Regs. $\$ 1.482-2(b)(1)$

${ }^{73}$ Wrappe, Steven C. and Trauman, Brian P TM Memorandum “The New Service Regulations: Are we There Yet?"

${ }^{74}$ Treas. Regs. $\$ 1.482-9 T(1)(3)(\mathrm{i})$

${ }^{75}$ IRC $\$ 6662(\mathrm{e})$

${ }^{76}$ Treas. Regs $§ 1.482-9 \mathrm{~T}$ (1)

${ }^{77}$ For example, Joseph Radtke, S.C. v. U.S., 895 F.2d 1196 (7th Cir. 1990).
} 


\section{CONCLUSION}

With the United States' movement to a services focused economy and the Service's emphasis on transfer pricing, it is imperative that companies address their related party services and document the analysis that was performed. Multinational companies need to make sure they understand the final provisions and perform the necessary steps to ensure compliance with the changes brought fourth by these regulations.

However, the Treasury regulations themselves leave many questions unanswered. Foremost is the question of how to calculate the value of services where there are no comparable services, as is frequently the case in complex transnational joint ventures. Second, there is the question of how other economic benefits to the provider of services will affect the determination of what qualifies as arm's-length compensation. Finally, there is the issue of whether other contract provisions, ranging from stock options to non-compete agreements, will affect the determination of what is compensation determined by arm's length negotiation. Just as 1968 marked a watershed year in acknowledging the need for transfer pricing rules related to services, we are now at a point where a whole new set of regulatios are requird to determine fair compensation in the modern economy.

\section{AUTHOR INFORMATION}

Martin A. Goldberg, J.D., LL.M., Associate Professor, University of New Haven College of Business Department of Accounting and Law, 300 Boston Post Road, West Haven, CT 06516. Contact author: Martin A. Goldberg.

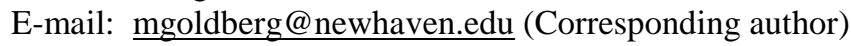

Robert E. Wnek, J.D., LL.M., CPA, Professor, University of New Haven College of Business Department of Accounting and Law, 300 Boston Post Road, West Haven, CT 06516. E-mail: rwnek@newhaven.edu

Jacqueline S. Pineau, M.S., University of New Haven College of Business Department of Accounting and Law, 300 Boston Post Road, West Haven, CT 06516. 


\section{NOTES}

